\title{
eLearning Penetration, Challenges and Opportunities in Saudi Arabia
}

\author{
Dimitrios Xanthidis ${ }^{1,3 *}$, Ourania Koutzampasopoulou Xanthidou ${ }^{2}$ and David Nicholas ${ }^{3}$, \\ 'Management Information Systems, Dhofar University, Oman, \\ dxanthidis@du.edu.om, \\ ${ }^{2}$ Computer Science and Information Technology, University of Malaya, Malaysia, \\ xarania@gmail.com \\ ${ }^{3}$ CIBER Research Ltd., Newbury, UK, CIBER-Research.eu, \\ dave.nicholas@gmail.com
}

\begin{abstract}
Objectives: The rapid advent of information technologies is addressing the role of location and time management in the education system. This exploratory study about eLearning developments in Saudi Arabia aims to reveal the current reality of eLearning progress in the country. More specifically, it seeks to find if Saudis are or, if otherwise, what is blocking this effort. Methods: A number of diverse types of administrative, technical and general challenges and issues related to this concept are covered. A pre-tested questionnaire was used during the data collection with data gathered from various individuals in Saudi Arabia. Findings: The Saudis are dissatisfied with the speed of the relevant developments and only blame the local telecommunications and other infrastructure not related to the academic institutions. Conclusions: It is believed that in just a short period of time eLearning systems will be fully utilized in the educational system like it happens in many other developed countries.
\end{abstract}

Keywords: Challenges, Education, eLearning, Opportunities, Preference, Saudi Arabia, Usage

\section{Introduction}

Although there is no clear definition for the term ${ }^{1}$ however eLearning is described as the use of the information and communication technologies (ICT from now on) to facilitate the easier and more efficient process for learning $\underline{2}$ through some type of online interaction between the teacher and the student or between colleagues ${ }^{\underline{3}}$. If no interaction occurs, then, it is simply distance learning rather than eLearning, 2 . Some see it as an effective substitute of traditional learning whereas others as the next big idea about learning that mitigates limitations of time and location that often exist in the learning process $2,5,6$.

There is a trend worldwide for the universities to incorporate eLearning practices in their daily operations; however, this does not come without problems in the administrative, technical or other domains especially in the developing countries ${ }^{7}$. Successful eLearning deployment means more than just ensuring access to the Internet and adequate IT literacy. It means addressing the hesitation because of older age, societies' value of traditional education, lack of understanding and appreciation of its value, that demotivate the individuals 
to get involved with such learning approaches 2,8 . The adoption of an efficient eLearning model rich in the use of multimedia (voice, visual, text) can boost eLearning performance enhancing the capacity of the traditional teaching and eliminating time and location barriers ${ }_{2,9,10}$.

Just implementing eLearning procedures and having in place the required infrastructure involves a number of challenges ranging from administrative to technological and pedagogical. There are several studies that suggest some of these concerns i.e., lack of efficient ICT infrastructure, problems with accessing the educational institutes, changes in technology, inadequate learning materials, not enough support from the institutions' management, the problem of the

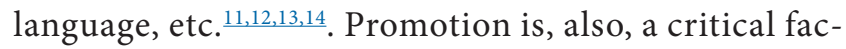
tor for the success of eLearning development $t^{\frac{15}{5}}$. From a technical perspective, the key requirements include addressing the issues of interoperability and maintenance, online registration, offering the appropriate programs, ensuring privacy and security, "authentication and internationalization of content, and support by other institutions" $\$, 11,16$.

Following a plan of heavy investments in digital communication infrastructures, since around 1995, that led to high Internet penetration rates ${ }^{17}$ (Qatar: $86.2 \%$, Bahrain: 77\%, Kuwait: $74.2 \%$, U.A.E.: 70.9\%, Oman: $68.8 \%$, Saudi Arabia: $49 \%$ ), it was, then, just a natural step forward to introduce eLearning in their tertiary education; this is more so in Saudi Arabia where the academic institutions are overwhelmed by the exceedingly large student enrollment attributed to the rapid population growth in the country ( $50 \%$ under 20$)^{18,19}$. Hence, promoting and progressing towards eLearning practices is seen as a "cost effective, convenient and efficient" model for all stakeholders ${ }^{20}$ and, perhaps, the only way to cope with the reality of rapid demographic increase ${ }^{18}$.

eLearning leads to the betterment of educational environment but requires successful leadership, willing and skilled instructors and motivated learners ${ }^{21}$. Inappropriate policies, insufficient funding, hesitation and other restrictions from the local societies, training issues, and inadequate ICT infrastructure, will lead to the failure of such an effort $\frac{11,22}{}$.

\section{Objectives and Methods}

This exploratory study about eLearning developments in Saudi Arabia aims to reveal the current reality of eLearning progress in the country. It is addressing the research question whether the local population is satisfied with this progress and, if not, what are the problems blocking such efforts. The specific investigative questions to be answered are:

- How do Saudis evaluate the status of eLearning development in their country?

- What do they see as possible obstacles and opportunities on the road to eLearning in their society?

- What are the administrative and technological challenges of eLearning the local society is facing?

- What would they perceive as strong promotional actions towards the goal of eLearning?

\subsection{Design of the Study Instrument}

The main problem to face was how to approach the participants given the several serious limitations e.g. language, religious restrictions, limited interest at large, large distances as a result of the size of the country, difficulty in reaching females ${ }^{\underline{z}}$. Age, gender and education of the participants were the control variables of the study; dichotomous was the choice between male and female for the gender, closedended structured categorization was for the age and education. The main instrument included targeted the investigative questions revealed through review of the literature ${ }^{2}$.

The instrument was moderated initially by 5 reputed individuals from local society, 3 academics and 2 professionals. In the revised version there some minor changes in the classifications of age to reflect the Saudi society ${ }^{2}$. Afterwards, this version was piloted by 20 conveniently selected individuals from the area of the capital Riyadh. This process ensured to a large extend the validity of the instrument ${ }^{11}$.

\subsection{The Sample ${ }^{2}$}

After the pilot test by the 20 individuals in Riyadh, the nonprobability convenient sampling was used. The questionnaire was either distributed (handed) to participants in the 4 main metropolitan regions of the country (the capital Riyadh, the main port of Jeddah, the east region of Damma, Khobar, Dahran, and the southwest region), or was self-administered using Google Docs 2 . The survey took place between March and June 2014 with 600 responses gathered initially. Once the proper checking 
of the data, in order to exclude erroneous responses (i.e. duplicates or empty responses), was completed the final set included 484 responses not all of them addressing all the investigative questions ${ }^{?}$.

The sample is considered as appropriate as to the gender given the difficulties in reaching the female population for their opinions (male 58.1\%, female $41.9 \%$ ) and as to the age since it is largely representative of following the general population relative pattern (i.e. "less than 18 ": 6.4\%, “18-25”: 46\%, “26-35”: 30.6\%, “36-45”: 14\%, “4660 ": $2.5 \%$, "More than 60 ": $0.7 \%)^{11}$. Finally, the sample is also satisfactory as to their education following rather closely the reality that has more than two thirds of the local population with some type of degree from higher education institutions or working towards it (diploma, undergraduate, graduate: $6.8 \%, 53.2 \%$, and $8.9 \%$ respectively).

The only problem is that the sample is far from representative as of the size of the aforementioned covered regions i.e. Riyadh: 233, Jeddah/ Mekka: 77, Dammam/ Khobar/ Dahran: 37, Abha: 47 respondents respectively. The final set of data was processed through SPSS for statistical calculations mainly cross-tabulations and analysis of variance (ANOVA). Excel was used to provide the charts 2 .

\section{Findings}

\subsection{Progress towards eLearning}

The vast majority of the participants (mean: 1.85, stand. dev.: 0.66 ) complain for slow (gender: $56.4 \%$, age: $57.1 \%$, education: $57.5 \%$ ) or no progress (gender: $25.6 \%$, age: $24.9 \%$, education: $25.4 \%$ ) of eLearning in Saudi universities. Less than a tenth (gender, age: $7.9 \%$, education: $7.6 \%$ ) are satisfied and only about $2 \%$ (gender: $2.1 \%$, age, education: $1.9 \%$ ) are really happy with eLearning developments in the country.

Statistics reveal a very small difference between males (1.81) and females (1.90) in regard to their opinions, i.e. very close to "slow progress" and it is rather unanimous (stand. dev.: females 0.53 , males 0.75 ). Things don't seriously change in the case of age (mean: 1.85, stand. dev.: 0.66) meaning age does not affect decisively the individual's view but only for the very young ages, i.e. less than 25, the pattern shifts a little closer to the complete dissatisfaction of "no progress" than in the other age ranges. The pattern stays generally the same when looking things from an education viewpoint (mean: 1.84, stand. dev.: 0.65). The only rather significant point here is that less educated individuals complain more about the "slow progress" than those more educated.

\subsection{General issues}

It suffices to say that only those individuals over 46 years old strongly agree with the suggested reasons, i.e. lack of necessary ICT infrastructure, language hurdles (especially concerning command of English), level of ICT literacy, financial issues, lack of eLearning institutions and lack of promotional strategies deployed, behind this slow development and only those with very low elementary (primary) education also agree more than the average mean (table 1, figure 1). However, it should be noted that due to the size of the sample a deeper study for these cases is necessary before safer conclusions could be made.

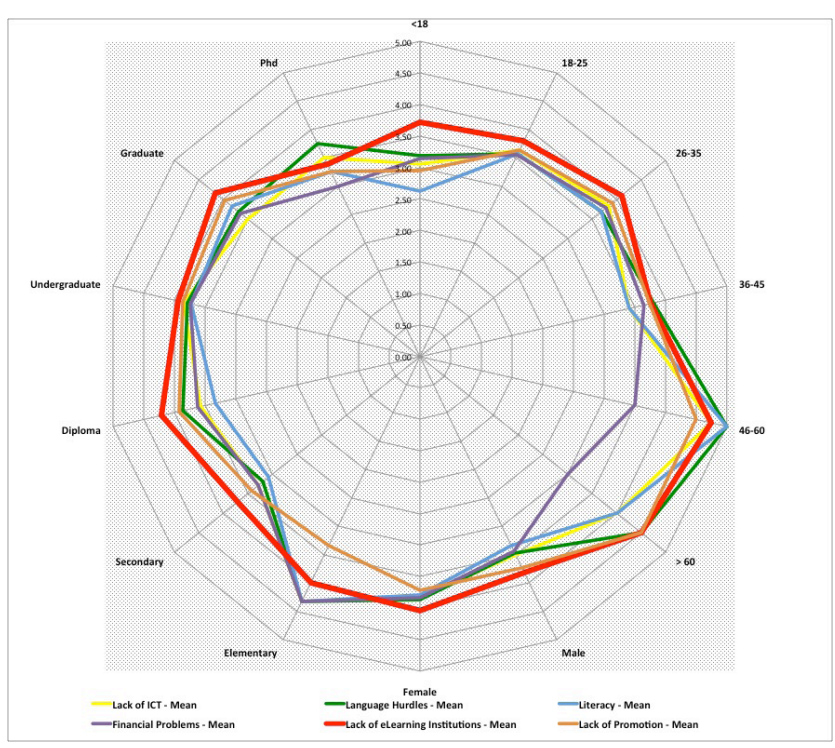

Figure 1. General reasons for slow or no progress of eLearning in Saudi Arabia.

One interpretation of the above findings could be that the participants' level of understanding and/or personal actual experience, on matters related to eLearning, in the country is low and, hence, they have difficulty in appreciating the weight of the suggested reasons making many of them rather "undecided" when addressing this issue. Another could be that depending on the location of their residence, e.g. whether close to the very developed capital of Riyadh or the large international port in the west, Jeddah, or in the rural areas of the vast desert 
Table 1. Mean (M) and standard deviation (SD) of general reasons for slow or no progress ${ }^{*}$

\begin{tabular}{|c|c|c|c|c|c|c|c|c|c|c|c|c|c|c|}
\hline & & \multicolumn{2}{|c|}{ Lack of ICT } & \multicolumn{2}{|c|}{$\begin{array}{l}\text { Language } \\
\text { Hurdles }\end{array}$} & \multicolumn{2}{|c|}{ Literacy } & \multicolumn{2}{|c|}{$\begin{array}{l}\text { Financial } \\
\text { Problems }\end{array}$} & \multicolumn{2}{|c|}{$\begin{array}{c}\text { Lack of eLearning } \\
\text { Institutions }\end{array}$} & \multicolumn{2}{|c|}{$\begin{array}{c}\text { Lack of } \\
\text { Promotion }\end{array}$} & \multirow[b]{2}{*}{$\mathrm{N}$} \\
\hline & Item & M & $\mathrm{SD}$ & M & $\mathrm{SD}$ & M & SD & M & $\mathrm{SD}$ & M & SD & M & SD & \\
\hline \multirow[t]{2}{*}{ Gender } & Male & 3.51 & 1.41 & 3.47 & 1.28 & 3.33 & 1.31 & 3.43 & 1.39 & 3.82 & 1.20 & 3.73 & 1.20 & 201 \\
\hline & Female & 3.82 & 1.30 & 3.87 & 1.24 & 3.79 & 1.17 & 3.83 & 1.30 & 4.04 & 1.12 & 3.72 & 1.20 & 140 \\
\hline \multirow[t]{6}{*}{ Age } & $<18$ & 3.05 & 1.66 & 3.19 & 1.29 & 2.62 & 1.36 & 3.14 & 1.31 & 3.71 & 1.35 & 2.95 & 1.07 & 21 \\
\hline & $18-25$ & 3.64 & 1.36 & 3.57 & 1.30 & 3.57 & 1.27 & 3.55 & 1.42 & 3.79 & 1.20 & 3.63 & 1.24 & 150 \\
\hline & $26-35$ & 3.83 & 1.26 & 3.69 & 1.25 & 3.68 & 1.18 & 3.79 & 1.25 & 4.10 & 1.04 & 3.91 & 1.12 & 110 \\
\hline & $36-45$ & 3.41 & 1.47 & 3.80 & 1.13 & 3.41 & 1.21 & 3.65 & 1.31 & 3.76 & 1.27 & 3.75 & 1.20 & 51 \\
\hline & $46-60$ & 4.75 & 0.50 & 5.00 & 0.00 & 5.00 & 0.00 & 3.50 & 1.73 & 4.75 & 0.50 & 4.50 & 0.58 & 4 \\
\hline & $>60$ & 4.00 & 0.00 & 4.50 & 0.71 & 4.00 & 0.00 & 3.00 & 2.83 & 4.50 & 0.71 & 4.50 & 0.71 & 2 \\
\hline \multirow[t]{6}{*}{ Education } & Elementary & 4.33 & 1.16 & 4.33 & 1.16 & 4.33 & 1.16 & 4.33 & 1.16 & 4.00 & 1.00 & 3.33 & 0.57 & 3 \\
\hline & Secondary & 3.29 & 1.53 & 3.19 & 1.39 & 3.08 & 1.43 & 3.29 & 1.47 & 3.70 & 1.34 & 3.42 & 1.31 & 84 \\
\hline & Diploma & 3.58 & 1.28 & 3.87 & 1.15 & 3.33 & 1.13 & 3.63 & 1.17 & 4.21 & 0.93 & 3.92 & 0.88 & 24 \\
\hline & Undergrad. & 3.85 & 1.27 & 3.79 & 1.21 & 3.73 & 1.18 & 3.75 & 1.33 & 3.94 & 1.12 & 3.86 & 1.17 & 179 \\
\hline & Graduate & 3.50 & 1.38 & 3.68 & 1.30 & 3.82 & 1.17 & 3.65 & 1.45 & 4.15 & 1.11 & 3.97 & 1.19 & 34 \\
\hline & $\mathrm{PhD}$ & 3.50 & 1.51 & 3.75 & 1.39 & 3.25 & 1.49 & 3.00 & 1.60 & 3.38 & 1.51 & 3.25 & 1.39 & 8 \\
\hline Totals & & 3.72 & 1.36 & 3.65 & 1.26 & 3.55 & 1.26 & 3.62 & 1.36 & 3.91 & 1.18 & 3.75 & 1.19 & \\
\hline
\end{tabular}

${ }^{*}$ Mean and Standard Deviation are calculated based on the responses organized on the Likert scale as "1. Strongly Disagree", "2. Disagree”, “3. Undecided”, “4. Agree”, “5. Strongly agree”.

largely underdeveloped or even completely undeveloped, the serious differences in the available infrastructure bring similar differences in individuals' reaction on their evaluation of eLearning and the expression on specific complains.

\subsection{Administrative Issues}

The views vary a lot when asked if "low quality of online curriculum" or "lack of support for usage training" cause the "slow or no progress" of eLearning in Saudi Arabia. In both cases there is a small trend towards rejecting the suggestions (41\% agree, 59\% disagree). Gender does not seem to affect the views and statistical analysis of the issue in cross-tabulation with age is not conclusive as there does not seem to be a clear pattern of any sort. Only in the case of education it looks that people with higher education complain more, i.e. they agree and, hence, answer "1. Yes". The pattern is mostly the same in the case where the issue of "no support from international institutions" is evaluated with the participants mostly disagreeing.

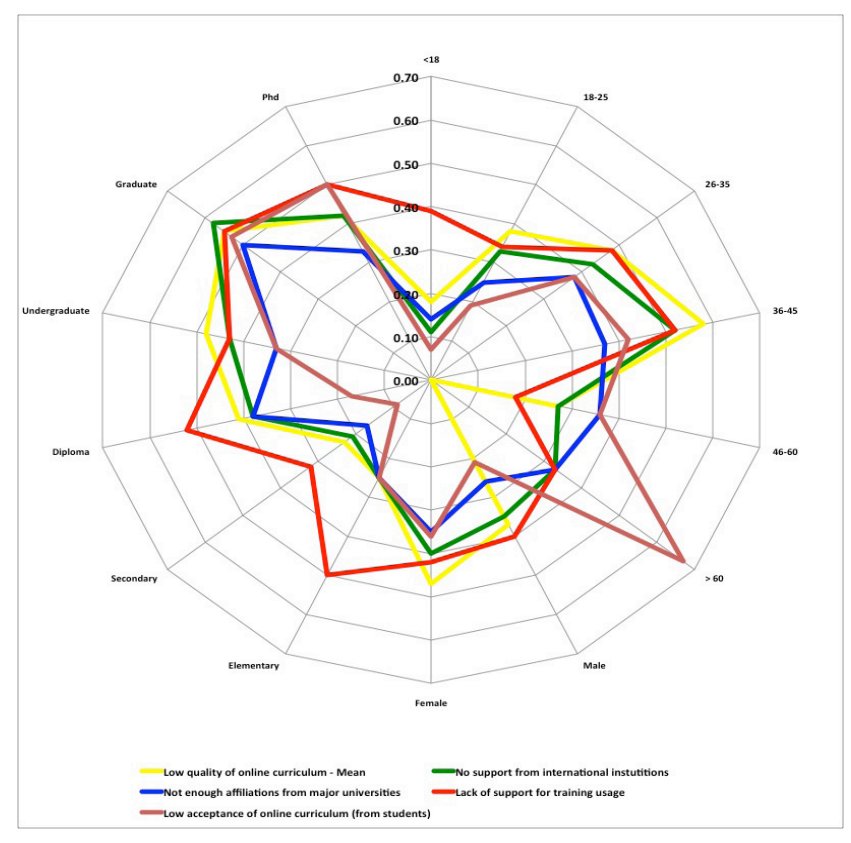

Figure 2. Administrative reasons for slow or no progress of eLearning in Saudi Arabia. 
Table 2. Administrative reasons for slow or no progress (Percentage of positive "1. Yes" responses)

\begin{tabular}{|l|c|c|c|c|c|c|c|}
\hline & & $\begin{array}{c}\text { Low quality } \\
\text { of online } \\
\text { curriculum }\end{array}$ & $\begin{array}{c}\text { No support from } \\
\text { international } \\
\text { institutions }\end{array}$ & $\begin{array}{c}\text { Not enough } \\
\text { affiliations } \\
\text { from major } \\
\text { universities }\end{array}$ & $\begin{array}{c}\text { Lack of } \\
\text { support for } \\
\text { usage training }\end{array}$ & $\begin{array}{c}\text { Low acceptance of } \\
\text { online curriculum } \\
\text { (by students) }\end{array}$ & N \\
\hline Gender & Male & $37 \%$ & $35 \%$ & $26 \%$ & $40 \%$ & $21 \%$ & 255 \\
\hline & Female & $47 \%$ & $40 \%$ & $35 \%$ & $42 \%$ & $36 \%$ & 184 \\
\hline Age & $<18$ & $18 \%$ & $11 \%$ & $14 \%$ & $39 \%$ & $7 \%$ & 28 \\
\hline \multirow{3}{*}{} & $18-25$ & $38 \%$ & $33 \%$ & $25 \%$ & $34 \%$ & $19 \%$ & 200 \\
\cline { 2 - 8 } & $26-35$ & $48 \%$ & $43 \%$ & $38 \%$ & $48 \%$ & $38 \%$ & 133 \\
\hline & $36-45$ & $58 \%$ & $52 \%$ & $37 \%$ & $52 \%$ & $42 \%$ & 60 \\
\hline & $46-60$ & $27 \%$ & $27 \%$ & $36 \%$ & $18 \%$ & $36 \%$ & 11 \\
\hline \multirow{2}{*}{ Education } & $>60$ & $0 \%$ & $33 \%$ & $33 \%$ & $33 \%$ & $67 \%$ & 3 \\
\hline & Elementary & $25 \%$ & $25 \%$ & $25 \%$ & $50 \%$ & $25 \%$ & 4 \\
\cline { 2 - 9 } & Secondary & $23 \%$ & $21 \%$ & $17 \%$ & $32 \%$ & $9 \%$ & 117 \\
\hline & Diploma & $41 \%$ & $38 \%$ & $38 \%$ & $52 \%$ & $17 \%$ & 29 \\
\hline & Undergrad. & $55 \%$ & $43 \%$ & $33 \%$ & $43 \%$ & $33 \%$ & 227 \\
\hline & Graduate & $55 \%$ & $58 \%$ & $50 \%$ & $55 \%$ & $53 \%$ & 38 \\
\hline Totals & PhD & $42 \%$ & $42 \%$ & $33 \%$ & $50 \%$ & $50 \%$ & 12 \\
\hline
\end{tabular}

The responses were a little more negative as to the suggestions of "not enough affiliations from major universities" and "low acceptance of online curriculum (by students)" as possible reasons of the "slow or no progress of eLearning" in the country (positive responses $30 \%$ and $27 \%$ respectively).

The main conclusion that can be drawn from the above is that although the majority see slow or no progress of eLearning in the country but they do not agree the problem is centered in those issues related with the administration of the online curriculum and the affiliation/ association with international institutions and major universities with relevant online programs. This could be either because they do not have a personal practical experience on eLearning and, therefore, they are not able to seriously evaluate the issues at hand or they do have the experience but don't see real problems as to the administration of eLearning related matters.

In any case the local decision makers on matters related to academia and eLearning must mainly focus on other possible reasons since it is mostly prevalent, from the participants' viewpoints of this study, that the local academic institutions are doing a good job in managing good quality eLearning services to their students. It just seems not to be satisfactory enough.

\subsection{Technical issues}

The individuals were suggested 5 different technical issues, that might be obstacles, related not just to eLearning but also generally to any online activity, namely, "personal privacy", "security breach", "administrative weaknesses", "limited access to educational software" and the reality of "rapidly changing ICTs".

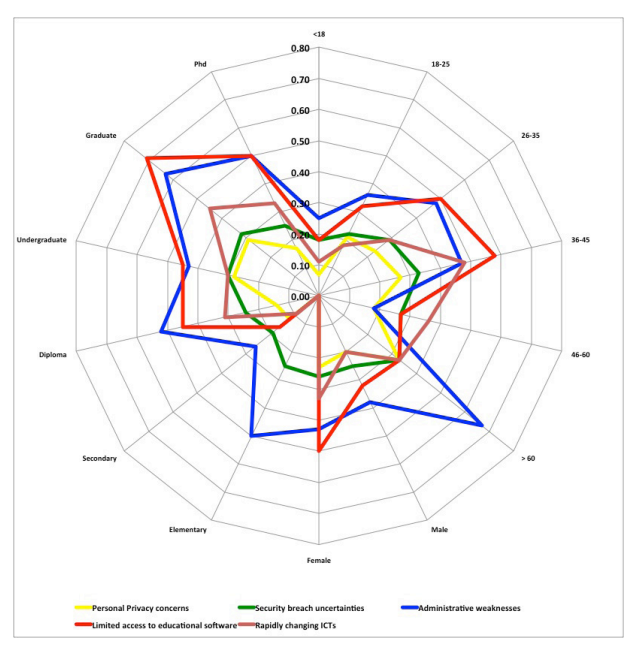

Figure 3. Technical reasons for slow or no progress of eLearning in Saudi Arabia. 
Table 3. Technical reasons for slow or no progress (Percentage of positive "1. Yes" responses)

\begin{tabular}{|c|c|c|c|c|c|c|c|}
\hline & & $\begin{array}{c}\text { Personal } \\
\text { Privacy } \\
\text { Concerns }\end{array}$ & $\begin{array}{l}\text { Security breach } \\
\text { concerns }\end{array}$ & $\begin{array}{l}\text { Administrative } \\
\text { weaknesses }\end{array}$ & $\begin{array}{l}\text { Limited access to } \\
\text { educational software }\end{array}$ & $\begin{array}{l}\text { Rapidly changing } \\
\text { ICTs }\end{array}$ & $\mathbf{N}$ \\
\hline \multirow[t]{2}{*}{ Gender } & Male & $20 \%$ & $25 \%$ & $38 \%$ & $32 \%$ & $20 \%$ & 255 \\
\hline & Female & $23 \%$ & $26 \%$ & $43 \%$ & $50 \%$ & $33 \%$ & 184 \\
\hline \multirow[t]{6}{*}{ Age } & $<18$ & $7 \%$ & $18 \%$ & $25 \%$ & $18 \%$ & $11 \%$ & 28 \\
\hline & $18-25$ & $21 \%$ & $22 \%$ & $36 \%$ & $32 \%$ & $18 \%$ & 200 \\
\hline & $26-35$ & $23 \%$ & $29 \%$ & $48 \%$ & $50 \%$ & $29 \%$ & 133 \\
\hline & $36-45$ & $27 \%$ & $33 \%$ & $47 \%$ & $58 \%$ & $48 \%$ & 60 \\
\hline & $46-60$ & $18 \%$ & $27 \%$ & $18 \%$ & $27 \%$ & $36 \%$ & 11 \\
\hline & $>60$ & $33 \%$ & $33 \%$ & $67 \%$ & $33 \%$ & $33 \%$ & 3 \\
\hline \multirow[t]{6}{*}{ Education } & Elementary & $0 \%$ & $25 \%$ & $50 \%$ & $0 \%$ & $0 \%$ & 4 \\
\hline & Secondary & $12 \%$ & $19 \%$ & $26 \%$ & $16 \%$ & $9 \%$ & 117 \\
\hline & Diploma & $14 \%$ & $24 \%$ & $52 \%$ & $45 \%$ & $31 \%$ & 29 \\
\hline & Undergrad. & $28 \%$ & $30 \%$ & $43 \%$ & $45 \%$ & $30 \%$ & 227 \\
\hline & Graduate & $29 \%$ & $32 \%$ & $63 \%$ & $71 \%$ & $45 \%$ & 38 \\
\hline & $\mathrm{PhD}$ & $17 \%$ & $25 \%$ & $50 \%$ & $50 \%$ & $33 \%$ & 12 \\
\hline Totals & & $22 \%$ & $26 \%$ & $41 \%$ & $39 \%$ & $26 \%$ & \\
\hline
\end{tabular}

In general, and following, more or less, the previous patterns the participants largely seem to, once again, disagree with the suggested technical aforementioned reasons. This is even more so in the cases of "personal privacy concerns", "security breach concerns" and "rapidly changing ICTs" (agree 22\%, 26\% and 26\% respectively). In the cases of "administrative weaknesses" and "limited access to educational software" the responses are just a bit more positive (agree $41 \%$ and $39 \%$ respectively).

A closer look of the stats shows that gender does not seriously affect the attitude of the individuals towards these issues. The only minor exception to this is that females complain just slightly more than males about the "limited access to educational software" (females: $50 \%$ for females, males: $32 \%$ ) and about the "rapidly changing ICTs (females: 33\%, males: 20\%). Furthermore, a similar analysis based on the age of the participants reveals an interesting fact that is the younger the age the less the individual cares about "privacy concerns" and "security breach" issues and likewise for those aged between 45-60. Likewise, in the case when education is the focus of the statistical analysis. It appears that the less educated a person is the less care is given to these technical issues but also if one holds a PhD that person is less likely to be concerned about such things as well.

A simple interpretation of these findings could be that the local individuals are not really concerned about these either perhaps because they don't realize their seriousness.

\subsection{Suggestions for Promoting eLearning}

The majority (59\%) believe that "advanced ICT/ Hardware" should be utilized for the promotion of eLearning and that "proper training on the eLearning systems" is necessary for the success of such a project (56\%). The opinions are split in the cases of the suggestions "utilize advanced ICT/Software", "establish advanced network connectivity" and "attract governmental/international sponsorships and scholarships" (agree: 52\%, 49\% and 50 respectively). For the cases "encourage and attract the affiliation and engagement of major universities" and "improve language skills" the general responses although again mostly divided but now they are slightly more negative (Table 4). 
Table 4. Suggestions on promoting eLearning (Percentage of positive "1. Yes" responses)

\begin{tabular}{|c|c|c|c|c|c|c|c|c|c|}
\hline & & $\begin{array}{l}\text { Advanced } \\
\text { ICT/ } \\
\text { Hardware }\end{array}$ & $\begin{array}{l}\text { Advanced } \\
\text { ICT/ } \\
\text { Software } \\
\end{array}$ & $\begin{array}{c}\text { Advanced } \\
\text { network } \\
\text { connectivity }\end{array}$ & Training & $\begin{array}{l}\text { Sponsorships/ } \\
\text { scholarships }\end{array}$ & $\begin{array}{l}\text { Affiliation } \\
\text { with major } \\
\text { universities }\end{array}$ & $\begin{array}{c}\text { Improve } \\
\text { language } \\
\text { skills } \\
\end{array}$ & $\mathrm{N}$ \\
\hline \multirow[t]{2}{*}{ Gender } & Male & $60 \%$ & $51 \%$ & $46 \%$ & $56 \%$ & $49 \%$ & $42 \%$ & $45 \%$ & 255 \\
\hline & Female & $57 \%$ & $53 \%$ & $52 \%$ & $57 \%$ & $52 \%$ & $46 \%$ & $49 \%$ & 184 \\
\hline \multirow[t]{6}{*}{ Age } & $<18$ & $61 \%$ & $57 \%$ & $43 \%$ & $50 \%$ & $39 \%$ & $36 \%$ & $43 \%$ & 28 \\
\hline & $18-25$ & $54 \%$ & $48 \%$ & $42 \%$ & $52 \%$ & $44 \%$ & $42 \%$ & $38 \%$ & 200 \\
\hline & $26-35$ & $64 \%$ & $60 \%$ & $59 \%$ & $65 \%$ & $56 \%$ & $43 \%$ & $57 \%$ & 133 \\
\hline & $36-45$ & $60 \%$ & $50 \%$ & $53 \%$ & $60 \%$ & $58 \%$ & $53 \%$ & $58 \%$ & 60 \\
\hline & $46-60$ & $64 \%$ & $27 \%$ & $27 \%$ & $55 \%$ & $64 \%$ & $45 \%$ & $45 \%$ & 11 \\
\hline & $>60$ & $67 \%$ & $33 \%$ & $33 \%$ & $67 \%$ & $0 \%$ & $0 \%$ & $0 \%$ & 3 \\
\hline \multirow[t]{6}{*}{ Education } & Primary & $25 \%$ & $50 \%$ & $50 \%$ & $50 \%$ & $25 \%$ & $75 \%$ & $25 \%$ & 4 \\
\hline & Secondary & $59 \%$ & $56 \%$ & $38 \%$ & $50 \%$ & $40 \%$ & $37 \%$ & $41 \%$ & 117 \\
\hline & Diploma & $76 \%$ & $66 \%$ & $59 \%$ & $76 \%$ & $66 \%$ & $52 \%$ & $66 \%$ & 29 \\
\hline & Undergrad. & $59 \%$ & $52 \%$ & $56 \%$ & $59 \%$ & $53 \%$ & $48 \%$ & $50 \%$ & 227 \\
\hline & Graduate & $53 \%$ & $39 \%$ & $32 \%$ & $50 \%$ & $45 \%$ & $34 \%$ & $37 \%$ & 38 \\
\hline & $\mathrm{PhD}$ & $50 \%$ & $50 \%$ & $50 \%$ & $42 \%$ & $58 \%$ & $25 \%$ & $50 \%$ & 12 \\
\hline Totals & & $59 \%$ & $52 \%$ & $49 \%$ & $56 \%$ & $50 \%$ & $43 \%$ & $47 \%$ & \\
\hline
\end{tabular}

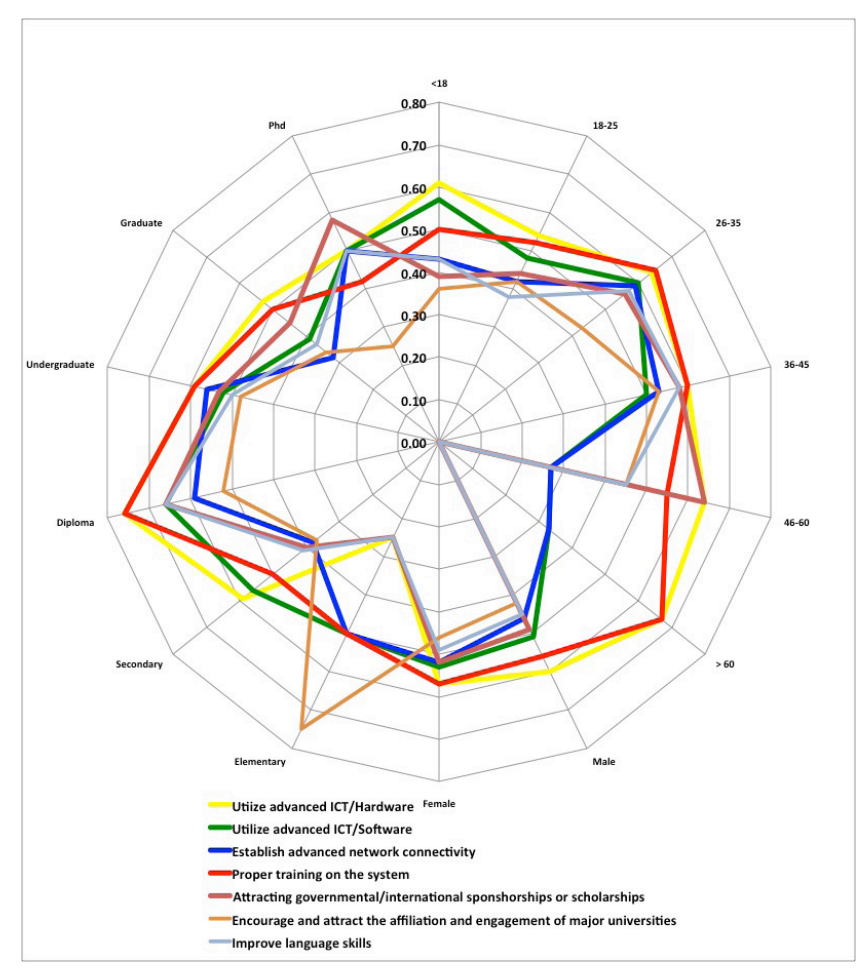

Figure 4. Suggestions on promoting eLearning in Saudi Arabia.
The gender does not affect the opinions and the age of the individuals seems to play a role that however, is not forming a specific pattern; likewise, with the results based on participants' education. The only point worth to note is that the elder people are slightly more negative to these suggestions than the younger except in the case of "attracting governmental/international sponsorship and scholarship" for which they seem a little more than positive than the rest.

The basic interpretation of these findings is that, most likely, the individuals are either not enough informed about the relevant issues related with the concept of eLearning and the ways to promote it or if they are informed their views are not quite clear on the matter as they show a serious level of confusion and, indeed, division in their responses.

\section{Conclusions}

Saudi universities move towards eLearning is considered slow. Constant effort is made towards this goal and, since 
Saudi Arabia is a rich country, one should only expect achievements to be clearly visible in the years to come. The whole educational system is still developing with this goal in mind, both public and private universities and the young population. Everyone is trying to familiarize with this type of educational approach at all levels, i.e. from the level of the universities management and their faculties to the students themselves.

The local academic institutions are not to blame for small progress but the main complaint is towards the ICT infrastructure and the lack of eLearning institutions. Also, following very closely behind the first two, illiteracy of a considerable part of the population and the problem of foreign languages, a necessity when aiming towards eLearning procedures, are the next serious reasons behind this slow development. Indeed, though it is quite apparent for the outsider that the young population, male and female, is both eager and strongly motivated, from a variety of governmental and other institutions, to be educated but it is also quite obvious that the literacy level of a very large part of this population is low, once again, given the standards of the developing countries ${ }^{11}$. Add to this the size of the country and the extensive inequalities and lack of any balance between the infrastructure and quality of institutions between the urban centers of Riyadh, Jeddah and Dammam and the rural areas of the vast desert and the reader gets a good idea of one more reason behind the shortcomings of eLearning in the country.

The financial issues that many educational units in the country, like many other business or other structures as well, are facing just very recently causes certain delays in both the promotion of this concept and its implementation. As far as the other requirements, in order for this plan to succeed, i.e. online curriculum, international support, international affiliations, student training, etc..$^{11}$ the majority of the participants of the study don't see any serious issues. This might be due to their limited education on such technologies and methods or their indifference on the relevant issues despite the fact these are serious focal points of discussion worldwide. It is only a matter of a few years' time for Saudi Arabia to get into the club of those countries with highly developed eLearning systems ${ }^{11}$. However, like in many other aspects of ICT it is essential for all stakeholders to first understand the key issues involved in it so as to avoid the possible hypes associated and move to the maturity stage of its usage in all fields including education ${ }^{22}$.

\section{References}

1. Sangrà AD. Vlachopoulos, N. Cabrera. Building an inclusive definition of e-learning: An approach to the conceptual framework. The International Review of Research in Open and Distributed Learning. 2012; 13(2):145-59.

2. Xanthidis D, A.S. Alali,O. Koutzampasopoulou, Online socializing: How does it affect the information seeking behavior and the educational preferences in Saudi Arabia? Computers in Human Behavior. 2016; 60:425-34.

3. Garrison DR. E-learning in the 21st century: A framework for research and practice. Taylor \& Francis. 2011.

4. Moore JL, C. Dickson-Deane, K. Galyen. e-Learning, online learning, and distance learning environments: Are they the same?. The Internet and Higher Education. 2011; 14(2): 129-35.

5. Shehabat IM, SAMahdi. E-Learning and its Impact to the Educational System in the Arab World. in Information Management and Engineering. ICIME'09. International Conference on IEEE. 2009.

6. Aixia D, D. Wang. Factors influencing learner attitudes toward e-learning and development of e-learning environment based on the integrated e-learning platform. International Journal of e-Education, e-Business, e-Management and e-Learning, 2011; 1(3): 264-8.

7. Xanthidis D, P. Nikolaidis. A preliminary study of eLearning penetration and potential in the GCC. in Computer Applications \& Research (WSCAR). World Symposium on IEEE. 2014.

8. Concannon F, A. Flynn, M. Campbell, What campus-based students think about the quality and benefits of e-learning. British journal of educational technology, 2005; 36(3): 501-12.

9. Salmon G, Flying not flapping: a strategic framework for e-learning and pedagogical innovation in higher education institutions. Research in Learning Technology, 2005; 13(3): 201-18.

10. Omidinia S, M. Masrom, H. Selamat. Determinants of Smart School System Success: A Case Study of Malaysia. International Journal of Academic Research, 2012; 4(1): 29-36.

11. Alali AS, D. Xanthidis. An exploratory study of eLearning challenges and opportunities in the GCC. in Computer Applications \& Research (WSCAR),World Symposium on IEEE. 2014.

12. Ahmadpour A, M. Mirdamadi. Determining challenges in the application of e-learning in Agricultural Extension Services in Iran. American-Eurasian Journal of Agriculture and Environmental Science, 2010; 9(3):292-6. 
13. Gulati S. Technology-enhanced learning in developing nations: A review. The International Review of Research in Open and Distributed Learning, 2008; 9(1): 1-16.

14. Ali G.E. , R. Magalhaes, Barriers to implementing e-learning: a Kuwaiti case study. International journal of training and development, 2008; 12(1): 36-53.

15. Selim HM. Critical success factors for e-learning acceptance: Confirmatory factor models. Computers \& Education, 2007; 49(2): 396-413.

16. Aguirre SJ, Quemada, J. Salvachúa. Integrated study programs through e-learning. IEEE Frontiers in Education Conference (FIE)on IEEE. 2010.

17. Internet world stats. Middle East Internet Users. Population and Facebook Statistics 2012 [cited copyrigth 30June 2012 August 2013]; Available from: Retrieved August 2013 http://www.internetworldstats.com/stats5.htm.
18. Xanthidis D, A.S. Alali. Effects of Social Media on eLearning development in the GCC. in Computer Applications \& Research (WSCAR), 2014 World Symposium on. IEEE. 2014.

19. Chanchary FH, S. Islam. Is Saudi Arabia ready for e-Learning? A case study, in International Arab Conference on Information Technology. 2011: Riyadh.

20. Al-Shehri AM. E-learning in Saudi Arabia:'To E or not to $\mathrm{E}$, that is the question. Journal of family and community medicine, 2010; 17(3): 147-50.

21. Abdelraheem, A.Y., The implementation of e-learning in the Arab Universities: Challenges and opportunities, in Proceedings of DLI 2006. Tokyo, Japan2006: . p. 145-55.

22. Alrawabdeh, W., Internet and the arab world: understanding the key issues and overcoming the barriers. Int. Arab J. Inf. Technol. 2009; 6(1): 27-32. 